\title{
26 Research Square \\ Stability of Enveloped and Nonenveloped Viruses in a Stable Gelatin Liquid Formulation
}

Francois Marie Ngako Kadji ( $\square$ fr-ngakokadji@nitta-gelatin.co.jp )

Nitta Gelatin Inc. https://orcid.org/0000-0002-9187-4584

\section{Kazuki Kotani}

Nitta Gelatin Inc., R\&D Center, Biomedical Department

Hiroshi Tsukamoto

Nitta Gelatin Inc., R\&D Center, Biomedical Department

Yosuke Hiraoka

Nitta Gelatin Inc., R\&D Center, Biomedical Department

Katsuro Hagiwara

Rakuno Gakuen University, School of Veterinary Medicine

\section{Research}

Keywords: virus, temperature, stability, gelatin

Posted Date: January 11th, 2022

DOI: https://doi.org/10.21203/rs.3.rs-1209181/v1

License: (c) (1) This work is licensed under a Creative Commons Attribution 4.0 International License. Read Full License 


\section{Abstract}

The thermal stability of relevant viruses in gelatin liquid formulations for medical research and application is poorly understood. Bovine herpesvirus (BHV) was used as a model virus to examine the molecular weight $(\mathrm{MW})$, concentration and gelatin type and to optimize virus stability in liquid formulations at $25^{\circ} \mathrm{C}$ and $4{ }^{\circ} \mathrm{C}$. Using the model virus stable liquid formulation, the stability of multiple enveloped and nonenveloped RNA and DNA viruses, including parainfluenza virus (PIV), reovirus (RV), $\mathrm{BHV}$, and adenovirus (AdV), was monitored over up to a 30-week storage period. The BHV model virus was considered stable after 3 weeks in hydrolyzed gelatin (MW: 4000) with a 0.8 LRV (log10 reduction value) at $25^{\circ} \mathrm{C}$ or a $0.2 \mathrm{LRV}$ at $4{ }^{\circ} \mathrm{C}$, compared to the stabilities observed in higher MW gelatin (60000 and 160000) with an LRV above 1. Based on the gelatin type, BHV in B-type gelatin samples were unexpectantly more stable than in A-type gelatin sample. All four viruses exhibited stability at $4{ }^{\circ} \mathrm{C}$ for at least 8 weeks, BHV or AdV remained stable for over 30 weeks of storage, and at $25^{\circ} \mathrm{C}, \mathrm{AdV}$ and RV remained stable for 8 weeks. The results demonstrated that $5 \%$ hydrolyzed gelatin can act as a relevant stabilizer for the thermal stability of viruses in medical research and application.

\section{Background}

Many viruses used for medical research or therapeutic purposes exhibit a lack of thermostability in ambient environments. Viruses can be placed in two main categories based on the presence or absence of an outer membrane around their capsid, namely,the lipid membrane, which classifies them as an enveloped ornonenvelopedvirus, respectively. The latter is more thermostable than the former group[1, 2].Theouter membrane ofenvelopedviruses is a lipid layer that plays a crucial role in virus lability and typically requires a temperature lower than $4{ }^{\circ} \mathrm{C}$ for short-or long-term storage. This group of viruses includes herpes simplex virus (HSV) andparainfluenzavirus (PIV), which are DNA and RNA viruses, respectively. HSV belongs to the Herpesviridae family and is divided into two types, namely,HSV-1 and HSV-2. The former is etiologically associated with oral herpes, while the latter is a potential cause of genital herpes. HSV-1 is considered an oncolytic virus after genetic modification for the treatment of diseases such as skin cancer[3-5]. PIV is divided into 4 types within the Paramyxoviridae family, including PIV-1, PIV-2, PIV-3, and PIV-4, and is most etiologically associated with respiratory infections[6].

On the other hand, in thenonenvelopedor naked virus category,adenovirus(AdV) in the Adenoviridae family and reovirus (RV) in the Reoviridae family are DNA and RNA viruses, respectively. Adenovirus is ubiquitous throughout the year and prevalent worldwide[7], and there are currently over 52 serotypes of AdV, such as serotypes $3,4,5,7$, and 14 , which can cause a wide range of illnesses, including lower respiratory and gastrointestinal infections[8]. Adenovirus is an extensively studied virus and chiefly used for virotherapy[9]or in vaccine as a viral vector,such as AdV-5 and AdV-26, in COVID-19 vaccines[10]. RV infection is mostly mild or subclinical but can lead to severe diarrhea in children, especially in those less than 5 years old[11]. The wild type RV also exhibits oncolytic properties, and it is currently being tested in several clinical trials in synergistic combination with immunotherapy for cancer treatment[12].Nevertheless, the stability of these enveloped andnonenvelopedmodel viruses in storage 
formulationsispoorly understood, and virus researchandhuman infectious disease researchoften employ animal-derivedvirus modelsin the virus families[13].

There are two main strategies currently used to improve virus stability:cold chain storage andfreezedrying. However, these strategies create some issues, including the challenges of cost and extensive infrastructure and maintenance for cold chain transport, especially for deepfreezing $[14,15]$.Thecost and potential loss of virus potency in the freeze-drying process or during reconstitutionaredue to protein destabilization, alteration of lipid layers (enveloped viruses), or occurrence of stressrelated to changes in the internal and external virus environment[16]. However,to improve these strategies, many excipients are used in the formulation to increasethethermal stability of viral particles, including sucrose, dextran, albumin, and gelatin. Gelatin is a bulking agent and acceptable material for medical use and can enhance virus stability at ambient temperatures. Gelatin is preferably used as a stabilizer due to its high biocompatibility, biodegradability, low immunogenicity, and low material cost[17]. Many investigators have used gelatin for decades as a stabilizer in vaccine development. For instance, it is an excipient in some vaccines approved by the FDA, including live attenuated influenza, measles mumps rubella, shingles zoster, varicella, and yellow fever vaccines under the brand names Flumist ${ }^{\circledR}, \mathrm{MMR} \|{ }^{\circledR}$, Zostavax ${ }^{\circledR}$, Varivax ${ }^{\circledR}$, and $Y F-V a x \circledast$,respectively. The contribution of gelatintovirus stability alleviates the cost and burden of transport and storage under the cold chain process, improving virus stability at ambient temperatures, including $4{ }^{\circ} \mathrm{C}$ and $25^{\circ} \mathrm{C}$.

Very few studieshavereported the thermal stability of viruses in gelatin formulations. Some studies have investigated the temperature-induced aggregation of measles particles in several stabilizing excipients, including gelatin[18], or the stability in sorbitol-gelatinformulationsfor measles virus[19]. Another report examined the thermal stability of varicella-zoster virus in hydrolyzed gelatin[20]. However, the characteristics of the gelatin product used for thermostability evaluation in those studiesarepoorly reported or unknown; there is a paucity of data on the thermal stability of viruses, including for enveloped andnonenvelopedviruses in gelatin liquidformulations.

The mechanism of gelatin-mediated stabilization of viral particles in liquid inoculant formulations remains broadly unknown. Gelatin is an additive that is thought to be a good stabilizer of viruses in viral transport medium [21]. Gelatin may also play a role in resistance to temperature-induced changes in viral density, which is often concluded from accelerated studies [18]. Moreover, the heterogeneous nature of gelatin makes explaining its mechanistic contribution to viral stability challenging. Many reports have speculated that gelatin might provide noncovalent binding via electrostatic interactions for virus stability [21]. In the case of cationized gelatin (introducing amine residues onto the carboxyl groups), a complex is formed with a negatively charged viral capsid or nucleic acid proteins through electrostatic interactions [22], which appears to prevent the degradation of surface proteins relevant to virus stability during storage or for the sustained release of an encapsulated drug in the body. It is also known that gelatin viscosity not only suppresses the phase transformation but also decreases osmotic pressure in protein solutions [23], and gelatin at an optimum concentration prevents virus aggregation, thereby improving stability through mutual incompatibility and special exclusion interactions with virus particles [24]. The 
properties of gelatin used in previous studies on the stability of viruses are poorly known. Therefore, this study aimed to examine the thermal stability of 4 enveloped and nonenveloped DNA and RNA viruses in liquid formulations with known gelatin parameters, including concentrations, molecular weights (MWs), and gelatin types, including type $A$ (acid extraction) and type B (basic extraction), to gain a greater understanding of their effects on virus stability profiles.

\section{Materials And Methods}

\section{Bulk virus preparation and storage}

Bovineherpesvirus 1 (BHV-1) asHerpesviridae, PI-3 (bovine parainfluenza type 3) as Paramyxoviridae, Reovirus 3 (RV-3; ATCC VR-824) as Reoviridae, andhuman adenovirus5 (AdV-5; ATCC VR-1516) as Adenoviridae were used as test viruses to examine virus thermal stability in gelatin liquidformulations. The BHV-1, PI-3, RV-3, and AdV-5 inoculums were prepared,and infected monolayers of MDBKcells(BHV-1 and PI-3), HEK-293 cells (AdV-5), and LLC-MK2 cells (RV-3)were culturedwithDulbecco'smodified Eagle's medium (DMEM; D6026 Merck) containing 5\% fetal calf serum followingincubation at $37^{\circ} \mathrm{Cfor}$ 6-7 days post-infection. Each virus-infected culture was harvested and centrifuged at 2500 rpmfor 15 mins at $4^{\circ} \mathrm{C}$, and the supernatantwas collected, transferred intoSW41TiBeckman UC tubes, andcentrifuged for2 hours at28Krpm to obtain purified virus stocks. Pellets were dissolved in gelatin liquid formulations. Aliquots of $250 \mu \mathrm{l} /$ tube were made and pretested to determine the initial virus titer, and the rest were stored at $-80^{\circ} \mathrm{C}$ as references and at ambient temperatures,including $4^{\circ} \mathrm{C}$ and $25^{\circ} \mathrm{C}$,for virus thermal stability evaluations.

\section{Gelatin samples}

The gelatin samples used for formulation wereofeither porcine or bovine origin. They included pigskin and bovine bone gelatinresultingfrom acid or basic extraction methods.Specifically, the samples were beMatrix series gelatin, including beMatrix HG, beMatrix gelatin LS-W, beMatrix gelatin LS-250, and beMatrix gelatin LS-H,from Nitta Gelatin Inc. (Osaka, Japan). Additionally, recombinant human serum albumin (rHSA) of molecular weight 66000 from Albumedix (Nottingham, UK) was also used as a reference control fortheviral stability test. VariousMWsof hydrolyzed gelatin were also obtained from one of the original products (beMatrix LS-H) through heat hydrolysis at differenttemperaturesandpH values,and the samples were all finally adjusted to $\mathrm{pH} 7$ prior to use in the formulations. Theresulting $\mathrm{MW}$ of thesampleswasmeasured by gel permeation chromatography following themanufacturer'sprotocol(Tosoh Bioscience). Briefly, a $0.2 \%$ gelatin solution adjusted with distilled water was passed through a $0.2 \mu \mathrm{m}$ filter andvortexed. The samples were placed in the autosampler for analysisunderthe following conditions:a $1 \mathrm{~mL} / \mathrm{min}$ flow rate, column temperature at $40{ }^{\circ} \mathrm{C}, 10 \mu \mathrm{L}$ injection volume, and a $214 \mathrm{~nm}$ UV wavelength. The isoelectric point determination for each sample wasperformedusing thezeta potential method with aZetaSizer Nano ZS (Malvern Panalytical,UK). Briefly, samples were dissolved in buffer made of a $0.1 \mathrm{MTris}-\mathrm{HCl}(\mathrm{pH} 7.7-9.0)$ solution and acetate solution $(\mathrm{pH}$ 
4.0-5.50) to make $0.25 \%(\mathrm{w} / \mathrm{v})$. Thezetapotential was measured,and the $\mathrm{pH}$ variation depending onthe zetapotential was plotted and extrapolated to derive the isoelectric point at zero[25].

\section{Cytotoxicity test}

To selectcytotoxicity-free samples for the gelatin formulation, a total of three buffers ( $6 \mathrm{mM}$ sodium phosphate+ $150 \mathrm{mM} \mathrm{NaCl}+10 \%$ glycerol[pH 7.2]; $20 \mathrm{mM}$ Tris + $25 \mathrm{mM} \mathrm{NaCl}+2.5 \%$ glycerol[pH 8.0]; and 6 mMsodium phosphate+ $150 \mathrm{mM} \mathrm{NaCl}+15 \%$ sucrose[pH 7.4]) and gelatin samples of variousMWswere evaluated. Briefly, each sample was seriallydiluted2-fold in DMEM (Dulbecco'smodifiedEagle'smedium) and dispensedat50 $\mu \mathrm{L} /$ well(triplicate) into a 96-well plate, followedby the addition of 10000 Vero cells per well andincubationat $37^{\circ} \mathrm{Cfor} 72$ hours. A volume of $20 \mu \mathrm{L}$ of M.T.S. (Promega G3580) was added and incubated at $37^{\circ} \mathrm{Cfor} 3$ hours, followed by absorbance measurement at $490 \mathrm{~nm}$ on a plate reader (Ultramark Microplate Reader, Bio-Rad). The survival rate was determined using the formula [Survival rate $=($ Sample O.D.- Blank $) /($ Mock OD- Blank) $\times 100]$.

\section{Virus titration}

Virus titration was carried out before and after storage at $-80^{\circ} \mathrm{C}, 4^{\circ} \mathrm{Cand} 25^{\circ} \mathrm{Cfor}$ a certain number of weeks. Briefly,triplicatesof aliquots for each virus sample before or after a storage period were seriallydiluted 10 -fold in cell medium; and inoculated onrelevant monolayers,including MDCK cells for BHV-1 and PI-3, HEK-293 cells for AdV-5, and LLC-MK2 cells for RV-3,in96-well plates; and incubated at37 ${ }^{\circ} \mathrm{C}$. The cytopathic effect was recorded 6 dayspost-infection. The virus titers were determined as the $50 \%$ tissue culture infectious dose $\left(\mathrm{TCID}_{50} / \mathrm{mL}\right)$ following the Karber method[26].The log10 reduction value (LRV) was calculated as the difference between the log 10 of preincubation virus titers and the log10 ofpost incubationvirus titers.AnLRV above 1 or over $90 \%$ reduction in titer was considered a loss of virus infectivity[27-30].

\section{Statistical analysis}

Data analysis, includinggroup comparisonsand graphical representations,wasconducted using Prism software 8.0 (GraphPad, San Diego, CA, USA), anda $P$ value $<0.05$ was considered statistically significant.

\section{Results}

GTS buffer (20 mM Tris-HCl, 2.5\% glycerol, $25 \mathrm{mM} \mathrm{NaCl}$ [pH 8.0]) and gelatin samples of various MWs with final concentrations ranging between $0.4 \%$ and $25 \%$ demonstrated no cytotoxicity (data not shown). In conducting the virus storage stability test, $\mathrm{BHV}-1$, which had the highest decrease in stability under $5 \%$ 
FCS DMEM conditions at $4^{\circ} \mathrm{C}$ for 4 weeks, was used as a model virus for the development of a stable liquid formulation.

In total, 5 samples with different gelatin molecular weights in the formulation in GTS buffer with BHV-1 were monitored primarily for 3 weeks at $25^{\circ} \mathrm{C}$ and $4^{\circ} \mathrm{C}$. BHV-1 remained stable after 3 weeks of storage in hydrolyzed gelatin liquid formulation at $25^{\circ} \mathrm{C}$, in contrast to the loss of stability observed in gelatin liquid formulations with 60000 and 160000 MWs. (Table 1). Additionally, BHV-1 remained stable in all three hydrolyzed gelatin liquid formulations at $4^{\circ} \mathrm{C}$ for 8 weeks of storage (Fig. 1).

Hydrolyzed gelatin with a molecular weight of 4000 , which demonstrated a better virus-stabilizing formulation at $4^{\circ} \mathrm{C}$ compared to that of other hydrolyzed gelatin samples, was singled out to make concentration-varying formulations of $0.1 \%, 0.5 \%, 5 \%, 10 \%$, and $20 \%(\mathrm{w} / \mathrm{w}) \%$ to find the optimal concentration for virus storage stability. In addition, $0.5 \%$ rHSA in GTS buffer was also used as a control in the same evaluation. Only the concentration of $5 \%$ showed good stability after 3 weeks of storage at $25^{\circ} \mathrm{C}$, while loss of rHSA stability occurred (Fig. 2A). Meanwhile, at $4^{\circ} \mathrm{C}$, hydrolyzed gelatin concentrations of $5 \%, 10 \%$ and $20 \%$ yielded good stability after 3 weeks of storage (Fig. $2 B$ ).

Additionally, analysis of BHV-1 stability according to gelatin type was performed, and the LRV of BHV-1 in A-type gelatin was approximately 4 times greater than the LRV of BHV-1 in gelatin type $\mathrm{B}$ at $25^{\circ} \mathrm{C}$ (Fig. 3).

To evaluate the effect of freezing and thawing samples multiple times on the stability of BHV-1, freezethaw stability testing was carried out, and the BHV-1 infectivity was preserved after three freeze-thaw cycles in liquid formulation without hydrolyzed gelatin. However, BHV-1 was significantly more stable in the hydrolyzed gelatin formulation than in the formulations without hydrolyzed gelatin (Fig. 4)

A long-term 30-week storage stability study of enveloped and nonenveloped, BHV-1, and AdV-5 in hydrolyzed gelatin MW 4000-based liquid formulation was carried out, and the results showed that the LRV was $\leq 1$ at $4^{\circ} \mathrm{C}$ and PI-3 and RV-3 also remained stable after 8 weeks storage (Fig. 5A-D).

\section{Discussion}

The experiments discussed above revealed the stability of enveloped and nonenveloped viruses in gelatin liquid formulations. The gelatin liquid formulations with high MWs of 60000 and 160000 showed a drastic loss of infectivity, which was over a $2 \mathrm{LRV}$, compared to that of hydrolyzed gelatin at $25^{\circ} \mathrm{C}$. The same experiment was not carried out at $4^{\circ} \mathrm{C}$ due to the high gelling factor of high-MW gelatin. A higher molecular weight had a negative effect on virus stability, which may likely be caused by the high viscosity factor disfavoring virus particle stability in the formulation. Another possibility is the greater loss of virus infectivity during the thawing of the gelled samples at $37^{\circ} \mathrm{C}$, which required a longer time to melt due to the higher gel strength than that of hydrolyzed gelatin in which there was no gelling strength and no thawing process was required after storage at $4^{\circ} \mathrm{C}$ or $25^{\circ} \mathrm{C}$ prior to the $\mathrm{CPE}$ assay. Among the hydrolyzed gelatin samples, the MW 4000 sample appeared to promote virus thermal stability at $25^{\circ} \mathrm{C}$ or $4^{\circ} \mathrm{C}$ compared to other hydrolyzed gelatin samples, and the concentration of $5 \%$ was found to be the 
optimum concentration to maintain virus stability. Hydrolyzed gelatin acts as an antioxidant and an electron donor to produce stable products prone to react with free radicals [31]. Hydrolyzed gelatin is commonly present in some vaccines at different concentrations as a stabilizer [32], and the optimal concentration may depend on the buffer or other ingredients in the formulation. All studied viruses exhibited stability at $4^{\circ} \mathrm{C}$ for at least 8 weeks, while BHV- 1 and AdV remained stable for over 30 weeks of storage. In this report, BHV-1 also remained stable for 3 weeks at $25^{\circ} \mathrm{C}$ showing an improved result over previous formulations. In another report, HSV stability lasted over a period of 39 weeks at $4^{\circ} \mathrm{C}$ in either a $0.5 \%$ partially hydrolyzed gelatin or an rHSA liquid formulation [33]. The difference observed could be explained by some factors, including the heterogeneous nature of hydrolyzed gelatin, the difference in buffer compositions used in each study, the virus species used for the stability test or, most likely, the initial virus stock. BHV and HSV both belong to the same Herpesviridae subfamily; HSV belongs to the Simplexvirus genus, and BHV belongs to the Varicellovirus genus [34]. However, progeny BHV-1 appear to comprise an abundance of capsidless, noninfectious light particles, in contrast to HSV, and both present variations in tegument content [35]. BHV-1 in GTS buffer without gelatin was stable at $-80^{\circ} \mathrm{C}(0.2 \log 10$ reduction) following 8 weeks of storage. Moreover, its stability was reduced $(0.7 \log 10)$ when it underwent a series of three freeze-thaw cycles and was significantly different compared to that in GTS with gelatin. The only difference between the two formulations in the freeze-thaw cycle test was the presence of gelatin; therefore, we speculate that the potential cryoprotective features of hydrolyzed gelatin used in this study in the freeze-thaw process positively impacted viral stability. The cryoprotective features of hydrolyzed gelatin have been previously reported with immune biomarkers [36] and food products [37] or probiotics [38,39], and further study is required to understand these features in the freezing process and their impact on virus stability.

The LRV of AdV- 5 was $0.6 \log 10$ following 30 weeks of storage at $4^{\circ} \mathrm{C}$. Previous studies have reported the stability of recombinant adenovirus at $4^{\circ} \mathrm{C}$ with an optimal formulation for 12 weeks or 24 months [40, 41]. There are possible factors contributing to the difference in the long-term 24-month (104 weeks) stability in the previous study [41] compared to that at 30 weeks in this study. These factors comprise the use of glass vials for virus storage and surfactants such as polysorbate 80 to additionally prevent virus adsorption to the glass surface or supplementary ingredients in the formulation in the other study, which are most likely required for longer storage times. However, wild-type adenovirus is known to be stable as a nonenveloped virus for multiple years at $-80^{\circ} \mathrm{C}$, but its stability profile at ambient temperatures, such as $4^{\circ} \mathrm{C}$ and $25^{\circ} \mathrm{C}$, is poorly known. In fact, the wild-type adenovirus used in this study is reported by the manufacturer to significantly drop in infectious titer following 12 months of storage at $-20^{\circ} \mathrm{C}$. Another study wherein the stability of an adenovirus strain in a lyophilized formulation lasted 24 weeks at $4^{\circ} \mathrm{C}$ [42] did not show greater stability than the stability over 30 weeks in liquid formulation in this study. Moreover, the adenovirus remained stable at $25^{\circ} \mathrm{C}$ following 8 weeks of storage compared to 1 month (4 weeks) at $30^{\circ} \mathrm{C}$ in the previous study. The improvement in virus stability, including for vaccine protection and oncolytic virus therapy, would alleviate the burdens caused by cold storage and widespread distribution.

Neither the PIV nor the RV models remained stable for 3 weeks of storage at $25^{\circ} \mathrm{C}$, in contrast to the DNA virus models used in this study. RV outer capsid components play an essential role in virus stability, and 
the inner core appears to be more thermostable than the outer capsid. The outer capsid protein $\sigma 3$ preserves infectivity by stabilizing the $\mu 1$ protein, which functions to penetrate the host cell membrane $[43,44]$, and its alteration by chemical or physical agents likely influences virus infectivity $[45,46]$. However, a higher infective stock virus titer may have improved the PIV and RV stability results because one of the factors of virus storage stability is the stock virus titer [33, 47]. In fact, PIV and RV stock titers were one thousand times lower than the BHV and AdV virus stock titers, which indicated that they were stable in the hydrolyzed gelatin liquid formulations. Hence, the poor stability profile of PIV and RV in hydrolyzed gelatin is most likely a result of low virus stock titers rather than the developed stable hydrolyzed gelatin liquid formulation. To confirm this assertion, another new virus stock was prepared to attain a higher titer for RV. The evaluation of stability with a higher titer in the same gelatin formulation revealed better stability compared to the stability with the lower virus titer (Supplementary Table 2).

Interestingly, among the hydrolyzed gelatin samples, those that resulted from basic extraction (gelatin B type) showed better results than the sample obtained by the acid extraction method (gelatin A type) with the BHV-1 model, and an interpretation of this finding would require further investigation. In general, the pl (isoelectric point) values of the $B$ and $A$ types are low (acidic) and high (basic), respectively. These hydrolyzed gelatin samples with pls of 5 or 8 were produced by alkaline and acid extraction methods, respectively. The pl of herpesvirus is reported to be approximately 9.6 [48]. There is a possible electrostatic interaction between the hydrolyzed gelatin with a pl of 5 and the herpesvirus to maintain virus surface protein stability during storage at the physiological $\mathrm{pH}$. These results should be interpreted

with caution. It is too preliminary to conclude that pls are a factor affecting virus stability. Further studies are needed to explore the potential effect of the gelatin pl on virus stability.

Nevertheless, this research has some limitations. The stability profiles of other viruses, including PIV, RV, and $\mathrm{AdV}$, with known gelatin parameters, such as MW, concentration, or extraction method, were not evaluated. Additionally, only the stability of BHV was evaluated in gelatin-free buffer or in freeze-thaw stability tests. Moreover, the effect of the current formulation on a vaccine model or genetically modified virus such as the oncolytic virus for potential immunogenicity retention or thermal stability were not evaluated and would be examined in a future study.

\section{Conclusion}

In summary, this study included the examination of the stability of four relevant viruses (enveloped/nonenveloped RNA/DNA viruses) in gelatin liquid formulations for storage in ambient environments. All virus models remained stable for 8 weeks, and BHV and AdV showed extended stability in the virus stable liquid formulation after 30 weeks of storage at $4^{\circ} \mathrm{C}$ in $5 \%$ hydrolyzed gelatin. The hydrolyzed gelatin used to develop the stable liquid formulation for all four model viruses was of pharmaceutical grade, had very low levels of endotoxin $(<10 \mathrm{EU} / \mathrm{g})$ and would be relevant for virus and medical research studies and applications.

\section{Abbreviations}


BHV, Bovine herpes virus; PIV, Parainfluenza virus; RV, Reovirus; AdV, Adenovirus; LRV, Log reduction value; MW, Molecular weight; COVID-19, Coronavirus disease 2019

\section{Declarations}

\section{Ethics approval and consent to participate}

Not applicable

\section{Consent for publication}

All authors read and approved the final manuscript.

\section{Availability of data and materials}

All data and material generated or analyzed in this study are available upon reasonable request and can be provided by Francois Marie Ngako Kadji () or Katsuro Hagiwara ()

\section{Conflicts of interest}

The authors declare noconflictsof interest.

\section{Funding}

Not Applicable

\section{Authors' contributions}

FK: study protocol development and manuscript drafting, KK: sample preparation and data management, YH: study protocol development and study supervision, $\mathrm{HT}$ : study protocol development and review, $\mathrm{KH}$ : study development, experimentation, data quality assurance and study supervision.

\section{Acknowledgments}

We are grateful to both the staff members of the research team in the Biomedical Department for their technical support in the study development and Kazuya Hayashi in the R\&D center for providing valuable 
information and comments regarding the research at Nitta Gelatin Inc. in Yao City, Osaka. We also thank Ms. Namiko Sawada for technical assistance in assays at Rakuno Gakuen University in Hokkaido.

\section{References}

1. Mahl MC, Sadler C. Virus survival on inanimate surfaces. Can J Microbiol. 1975;21(6):819-23.

2. Firquet S, Beaujard S, Lobert PE, Sané F, Caloone D, Izard D, Hober D. Survival of Enveloped and NonEnveloped Viruses on Inanimate Surfaces. Microbes Environ. 2015;30(2):140-4.

3. Malkin JE. Epidemiology of genital herpes simplex virus infection in developed countries, Herpes 11 Suppl 1 (2004) 2A-23A.

4. Varghese S, Rabkin SD. Oncolytic herpes simplex virus vectors for cancer virotherapy. Cancer Gene Ther. 2002;9(12):967-78.

5. Kaufman HL, Kohlhapp FJ, Zloza A. Oncolytic viruses: a new class of immunotherapy drugs. Nat Rev Drug Discov. 2015;14(9):642-62.

6. Goldman's Cecil Medicine (Twenty-Fourth Edition), 2012.

7. Lynch JP, Fishbein M, Echavarria M. Adenovirus Semin Respir Crit Care Med. 2011;32(4):494-511.

8. Ghebremedhin B. Human adenovirus: Viral pathogen with increasing importance. Eur J Microbiol Immunol (Bp). 2014;4(1):26-33.

9. Gonzalez-Pastor R, Goedegebuure PS, Curiel DT. Understanding and addressing barriers to successful adenovirus-based virotherapy for ovarian cancer, Cancer Gene Ther (2020).

10. Forni G, Mantovani A. R.m. COVID-19 Commission of Accademia Nazionale dei Lincei, COVID-19 vaccines: where we stand and challenges ahead. Cell Death Differ. 2021;28(2):626-39.

11. Lanata CF, Fischer-Walker CL, Olascoaga AC, Torres CX, Aryee MJ, Black RE. C.H.E.R.G.o.t.W.H.O.a. UNICEF, Global causes of diarrheal disease mortality in children $<5$ years of age: a systematic review. PLoS One. 2013;8(9):e72788.

12. Phillips MB, Stuart JD, Rodríguez Stewart RM, Berry JT, Mainou BA, Boehme KW. Current understanding of reovirus oncolysis mechanisms. Oncolytic Virother. 2018;7:53-63.

13. Ruiz SI, Zumbrun EE, Nalca A. Animal Models of Human Viral Diseases. In: Conn PM, editor. Animal Models for the Study of Human Disease. Elsevier Inc; 2013. pp. 927-70.

14. Hsiao A, Desai SN, Mogasale V, Excler JL, Digilio L. Lessons learnt from 12 oral cholera vaccine campaigns in resource-poor settings. Bull World Health Organ. 2017;95(4):303-12.

15. Yu YB, Briggs KT, Taraban MB, Brinson RG, Marino JP. Grand Challenges in Pharmaceutical Research Series: Ridding the Cold Chain for Biologics. Pharm Res. 2021;38(1):3-7.

16. Hansen LJJ, Daoussi R, Vervaet C, Remon JP, De Beer TRM. Freeze-drying of live virus vaccines: A review. Vaccine. 2015;33(42):5507-19.

17. Su K, Wang C. Recent advances in the use of gelatin in biomedical research. Biotechnol Lett. 2015;37(11):2139-45. 
18. Kissmann J, Ausar SF, Rudolph A, Braun C, Cape SP, Sievers RE, Federspiel MJ, Joshi SB, Middaugh CR. Stabilization of measles virus for vaccine formulation. Hum Vaccin. 2008;4(5):350-9.

19. de Rizzo E, Tenório EC, Mendes IF, Fang FL, Pral MM, Takata CS, Miyaki C, Gallina NM, Tuchiya HN, Akimura OK. Sorbitol-gelatin and glutamic acid-lactose solutions for stabilization of reference preparations of measles virus. Bull Pan Am Health Organ. 1989;23(3):299-305.

20. Liska V, Bigert SA, Bennett PS, Olsen D, Chang R, Burke CJ. Evaluation of a recombinant human gelatin as a substitute for a hydrolyzed porcine gelatin in a refrigerator-stable Oka/Merck live varicella vaccine. J Immune Based Ther Vaccines. 2007;5:4.

21. Johnson FB. Transport of viral specimens. Clin Microbiol Rev. 1990;3(2):120-31.

22. Fukunaka Y, Iwanaga K, Morimoto K, Kakemi M, Tabata Y. Controlled release of plasmid DNA from cationized gelatin hydrogels based on hydrogel degradation. J Control Release. 2002;80(1-3):33343.

23. Loeb J, THE RECIPROCAL RELATION BETWEEN THE OSMOTIC PRESSURE AND THE VISCOSITY OF GELATIN SOLUTIONS. J Gen Physiol. 1921;4(1):97-112.

24. Dudman WF. Interaction between gelatin solutions and tobacco mosaic virus. Biochim Biophys Acta. $1966 ; 120(2): 212-21$.

25. Macovescu G. Validation of method for determining the isoelectric point of protein solutions. Leather footwear journal. 2018;18(1):53-66.

26. K. G, Beitrag zur kollektiven Behandlung pharmakologischer Reihenversuche., Archiv f experiment Pathol u Pharmakol. 162 (1931) Four 480 - 483.

27. Croyle MA, Cheng X, Wilson JM. Development of formulations that enhance physical stability of viral vectors for gene therapy. Gene Ther. 2001;8(17):1281-90.

28. Drug Stability: Principles and Practices, 2nd edn, Drugs and the Pharmaceutical Sciences vol. 68 Marcel Dekker: New York 1995.

29. International Conference on Harmonization (ICH). Harmonized Tripartite Guideline, Stability Testing of New Drug Substances and Products 1993.

30. Galazka JMA, Zaffran M. Thermostability of vaccines, World health organization, 1998.

31. Wang J, Luo D, Liang M, Zhang T, Yin X, Zhang Y, Yang X, Liu W. Spectrum-Effect Relationships between High-Performance Liquid Chromatography (HPLC) Fingerprints and the Antioxidant and Anti-Inflammatory Activities of Collagen Peptides, Molecules 23(12) (2018).

32. Potential Vaccine Allergens. https://www.vaccinesafety.edu/Components-Allergens\%2021-0115.pdf. 2021).

33. LITOWSKI JR, SISKA, Christine KERWIN, Arthur B. Stable frozen herpes simplex virus formulation. In: Property WI, Organization, editors. International Bureau. US: AMGEN INC.; 2016.

34. Zaichick SV, Bohannon KP, Smith GA. Alphaherpesviruses and the cytoskeleton in neuronal infections. Viruses. 2011;3(7):941-81. 
35. Russell T, Bleasdale B, Hollinshead M, Elliott G. Qualitative Differences in Capsidless L-Particles Released as a By-Product of Bovine Herpesvirus 1 and Herpes Simplex Virus 1 Infections, J Virol 92(22) (2018).

36. Yasui K, Fujioka H, Nakamura Y. Cryoprotective effect of gelatin and albumin on recombinant human tumor necrosis factor liposome. Chem Pharm Bull (Tokyo). 1993;41(12):2138-40.

37. Yasemi M. Prevention of denaturation of freshwater crayfish muscle subjected to different freezethaw cycles by gelatin hydrolysate. Food Chem. 2017;234:199-204.

38. Chen X, Li L, Yang F, Wu J, Wang S. Effects of gelatin-based antifreeze peptides on cell viability and oxidant stress of Streptococcus thermophilus during cold stage. Food Chem Toxicol. 2020;136:111056.

39. Hubálek Z. Protectants used in the cryopreservation of microorganisms. Cryobiology. 2003;46(3):205-29.

40. Bajrovic I, Schafer SC, Romanovicz DK, Croyle MA. Novel technology for storage and distribution of live vaccines and other biological medicines at ambient temperature. Sci Adv. 2020;6(10):eaau4819.

41. Evans RK, Nawrocki DK, Isopi LA, Williams DM, Casimiro DR, Chin S, Chen M, Zhu DM, Shiver JW, Volkin DB. Development of stable liquid formulations for adenovirus-based vaccines. J Pharm Sci. 2004;93(10):2458-75.

42. Jha BK. Effect of Lyophilization on Infectivity and Viral Load of Adenovirus. Nepal Journal of Biotechnology. 2015;3(1):15-21.

43. Snyder AJ, Wang JC, Danthi P. Components of the Reovirus Capsid Differentially Contribute to Stability, J Virol 93(2) (2019).

44. Thete D, Snyder AJ, Mainou BA, Danthi P. Reovirus $\mu 1$ Protein Affects Infectivity by Altering VirusReceptor Interactions. J Virol. 2016;90(23):10951-62.

45. Drayna $D$, Fields BN. Biochemical studies on the mechanism of chemical and physical inactivation of reovirus. J Gen Virol. 1982;63(Pt 1):161-70.

46. Drayna D, Fields BN. Genetic studies on the mechanism of chemical and physical inactivation of reovirus. J Gen Virol. 1982;63(Pt 1):149-59.

47. Wang X, Zoueva 0 , Zhao J, Ye Z, Hewlett I. Stability and infectivity of novel pandemic influenza A (H1N1) virus in blood-derived matrices under different storage conditions. BMC Infect Dis. 2011;11:354.

48. Nealon K, Newcomb WW, Pray TR, Craik CS, Brown JC, Kedes DH. Lytic replication of Kaposi's sarcoma-associated herpesvirus results in the formation of multiple capsid species: isolation and molecular characterization of $A, B$, and $C$ capsids from a gammaherpesvirus. J Virol. 2001;75(6):2866-78.

\section{Tables}

Due to technical limitations, tables are only available as a download in the Supplemental Files section. 
Figures

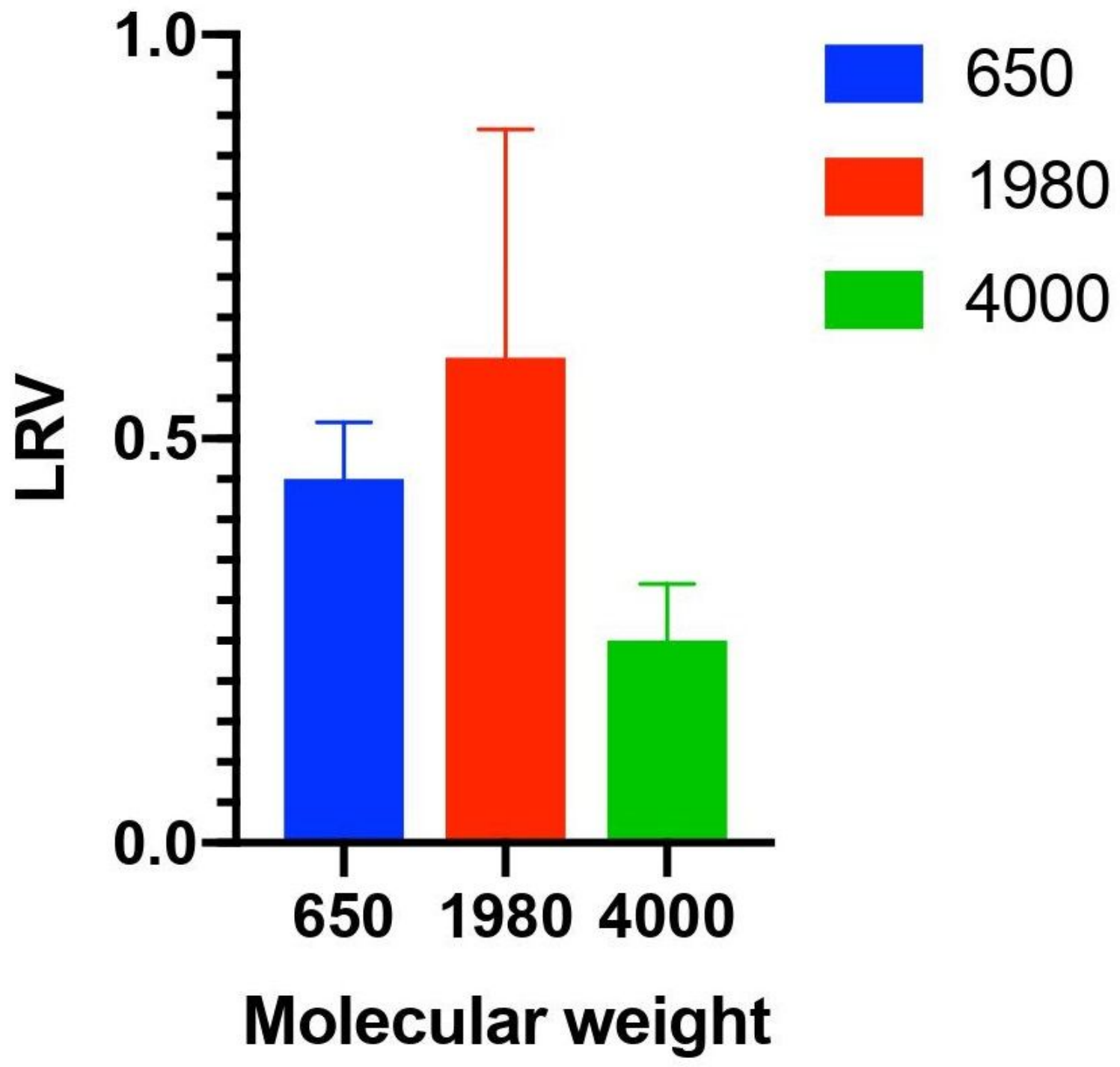

Figure 1

Stability over 3 weeks of storage of BHV-1 in the hydrolyzed gelatin liquid formulation at $4{ }^{\circ} \mathrm{C}$. 

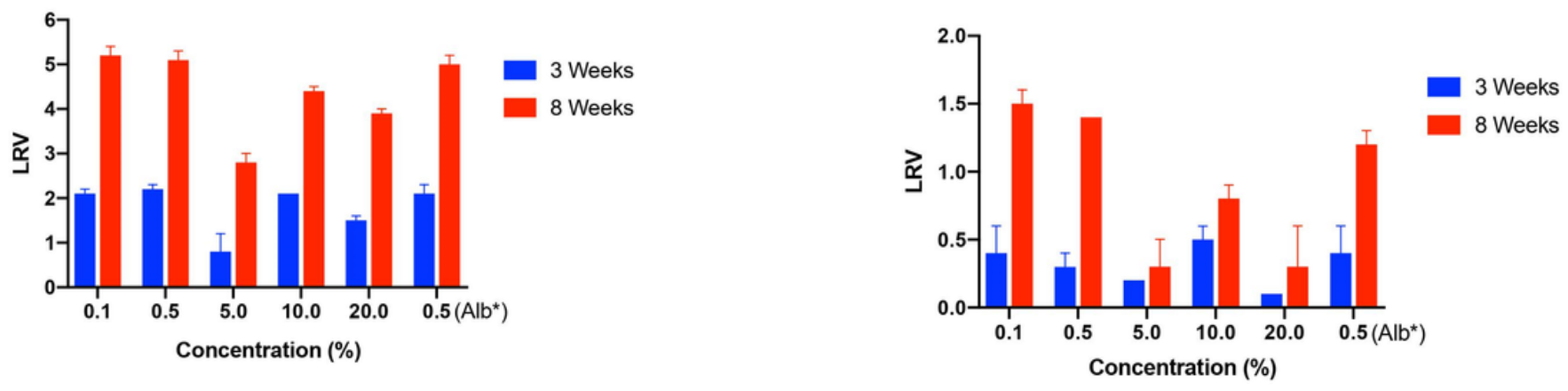

\section{Figure 2}

A. Stability of $\mathrm{BHV}$ in the hydrolyzed gelatin liquid formulation with varying concentrations in 3- and 8week storage at $25^{\circ} \mathrm{C}$.

B. Stability of BHV in hydrolyzed gelatin liquid formulation with varying concentrations in 3- and 8-week storage at $4{ }^{\circ} \mathrm{C}$ 


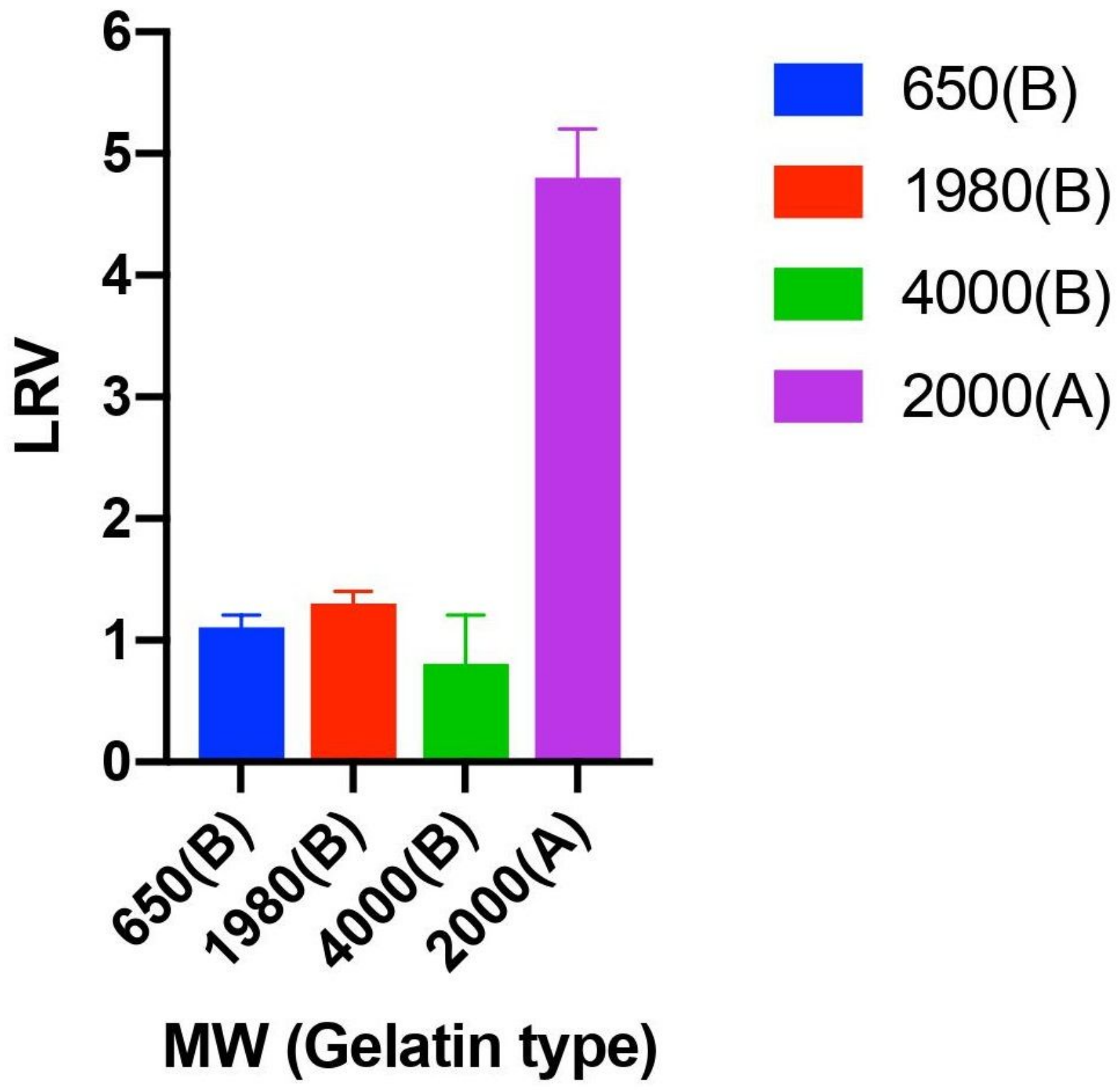

Figure 3

Stability of BHV in hydrolyzed gelatin types $\mathrm{A}$ and $\mathrm{B}$ after 3 weeks of storage at $25^{\circ} \mathrm{C}$. 


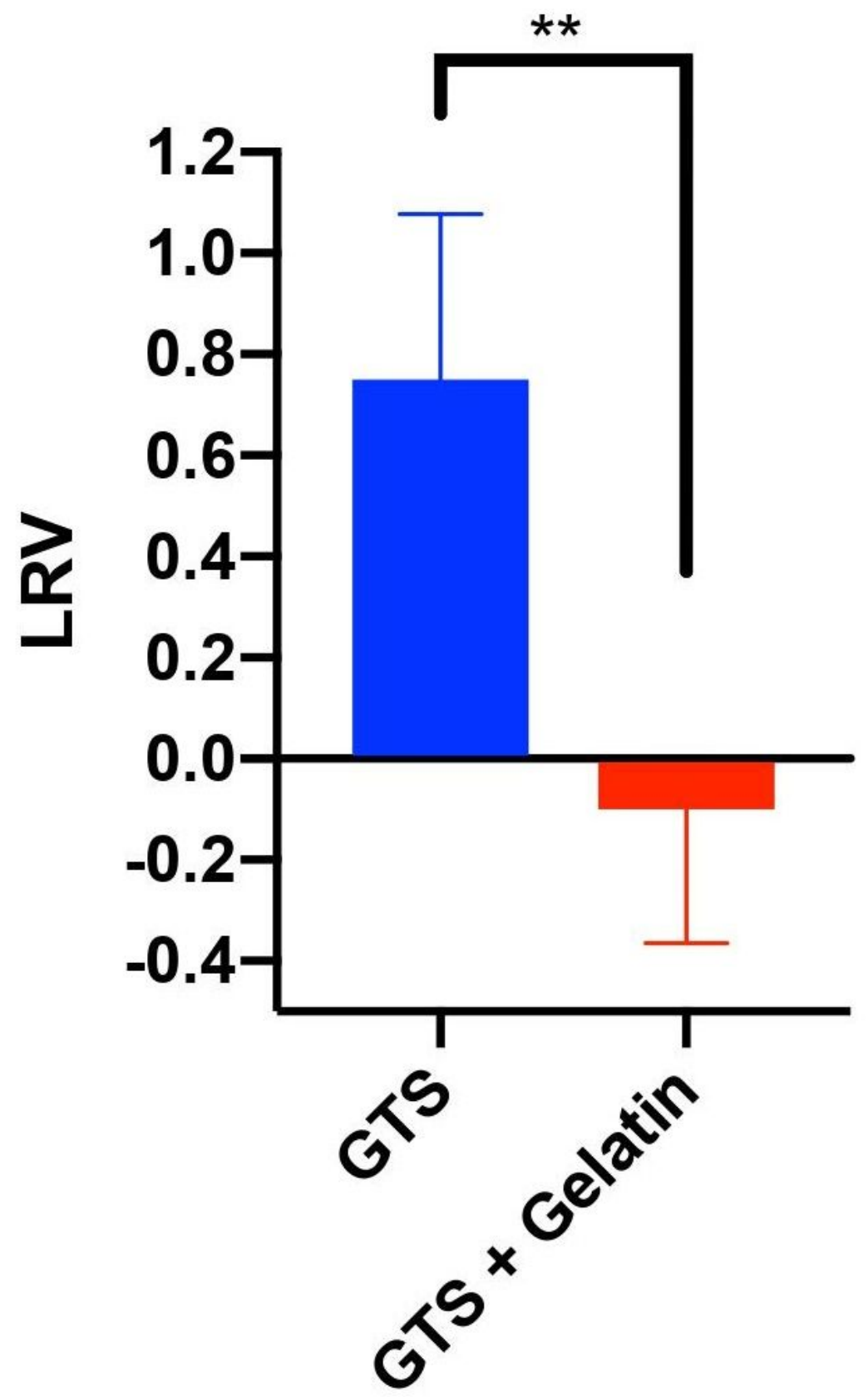

GTS

GTS + Gelatin

Figure 4

Effect of freeze-thaw cycles on BHV stability in hydrolyzed gelatin.

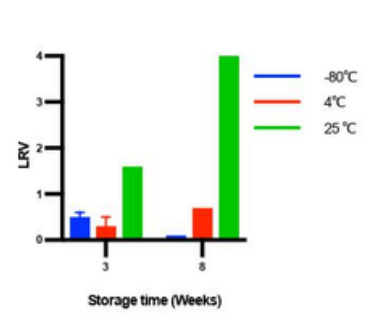

a

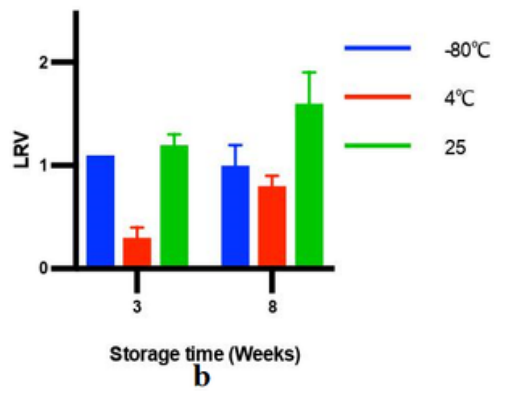

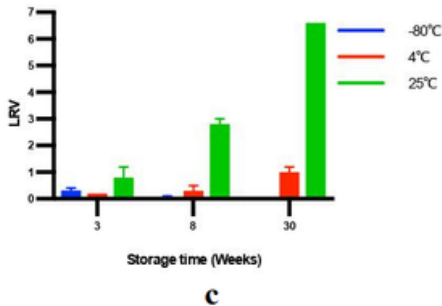

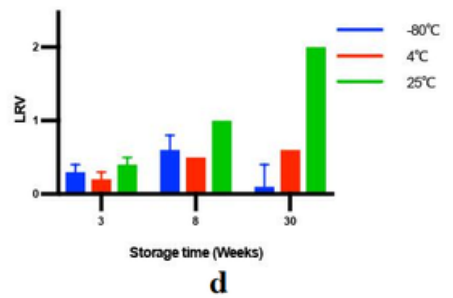




\section{Figure 5}

(A). Stability of PIV in the hydrolyzed gelatin liquid formulation over 30 weeks of storage at $-80^{\circ} \mathrm{C}, 4^{\circ} \mathrm{C}$ and $25{ }^{\circ} \mathrm{C}$ with a stock virus titer of $2 \times 10^{5.5} \mathrm{TCID} 50 / \mathrm{ml}$.

(B). Stability of RV in the hydrolyzed gelatin liquid formulation over 30 weeks of storage at $-80^{\circ} \mathrm{C}, 4^{\circ} \mathrm{C}$ and $25^{\circ} \mathrm{C}$ with a stock virus titer of $2 \times 10^{5.2}$

$\mathrm{TCID} 50 / \mathrm{ml}$.

(C). Stability of $\mathrm{BHV}$ in the hydrolyzed gelatin liquid formulation over 30 weeks of storage at $-80^{\circ} \mathrm{C}, 4^{\circ} \mathrm{C}$ and $25^{\circ} \mathrm{C}$ with a stock virus titer of $2 \times 10^{8.1} \mathrm{TCID} 50 / \mathrm{ml}$.

(D). Stability of $\mathrm{AdV}$ in the hydrolyzed gelatin liquid formulation over 30 weeks of storage at $-80^{\circ} \mathrm{C}, 4^{\circ} \mathrm{C}$ and $25^{\circ} \mathrm{C}$ with a stock virus titer of $2 \times 10^{8.0} \mathrm{TCID} 50 / \mathrm{ml}$.

\section{Supplementary Files}

This is a list of supplementary files associated with this preprint. Click to download.

- TablesStabilityofvirusesingelatin.pdf 